\title{
ARTE Y TEATRALIDAD EN SANTA
}

\author{
POR \\ Martha Elena Munguía Zatarain \\ Universidad Veracruzana
}

La asociación de teatro y prostitución tiene una larga historia y estas relaciones se han estudiado desde muy distintas perspectivas; han sido particularmente iluminadoras las reflexiones elaboradas desde la sociología y la antropología para entender el fenómeno: la prostituta que concurre a teatros y centros de diversión; la vieja reputación dudosa de actrices y comediantes; ${ }^{1}$ la presencia de la prostituta como ser ficcional, vestida, maquillada para un particular performance; la decoración de los prostíbulos como fascinante escenografía de ámbitos exóticos, son algunos de los aspectos más analizados de esta relación. Por lo demás, ciertos trabajos críticos se han encargado de señalar el hecho innegable de que gran parte de la narrativa orientada hacia la recreación del ámbito prostibulario recurre a estrategias originadas en la dramaturgia para hacer más plástico y contundente el mundo ficcionalizado, y esto no ha sido excepción en la abundante bibliografía crítica sobre Santa. ${ }^{2}$

En este trabajo voy a explorar algunas de las dimensiones de esta rica y compleja relación entre teatro y prostitución para explicar uno de los aspectos de la propuesta ética y estética de Santa, en tanto novela paradigmática, indudablemente vigente y provocadora. Me parece que es pertinente orientar la búsqueda en esta dirección

\footnotetext{
1 A este respecto resulta muy interesante el trabajo de Serge Salaün donde intenta ubicar el papel del teatro a principios del siglo xx en España, tradición que no nos es para nada ajena: "Todos los teatros, cafés cantantes, cabarets y demás establecimientos dedicados a los espectáculos están vinculados con la prostitución, con el consumo sexual, con la cultura prostitucional más o menos encubierta, pero real. Los teatros 'tradicionales' o burgueses (ópera incluida) siempre han servido para operaciones matrimoniales, enlaces o encuentros (es decir, son una institución tradicionalmente útil para la vida privada y afectiva) y las actrices o cantantes -las jóvenes y atractivas, evidentemente- siempre se han dedicado a lo que se sigue llamando hasta la guerra 'galantería', o 'coqueteo': es el lugar de las 'cocottes', de las 'demimondenes', de las señoritas 'protegidas', etc.” (44).

2 Manuel Prendes es uno de los estudiosos de la obra de Gamboa que ha dedicado atención al efecto teatral que busca producir el autor en su deliberada ubicación de las acciones novelescas en interiores; también ve como rasgo teatral la demorada descripción de espacios para crear una determinada ambientación y reconoce este recurso como resultado de una actitud fundamentalmente realista que buscaba crear un realismo escénico (353-363).
} 
porque puede ayudar a arrojar una luz nueva sobre la conformación literaria del burdel como un espacio moral y artístico desde donde se articula una compleja visión del tiempo histórico de la nación, del rol de hombres y mujeres, de las posibilidades de la sexualidad; un acercamiento al territorio del erotismo y una reflexión sobre el valor y el sentido del arte; y, en estos términos, tal vez un análisis como el que aquí propongo podría contribuir con un elemento más que ayude a explicar el por qué de la vigencia y vitalidad de esta novela.

Lourdes Franco analiza el primer capítulo de Santa y el de Naná para demostrar la diferencia fundamental en la estética de ambas novelas. Señala que Naná se inicia en un teatro, con lo que se señala que:

[...] el espacio en el que habrá de llevarse a cabo el relato de la vida de Naná es ilusivo y por tanto, lo que en él ocurra habrá de leerse como una impostura de los sentidos. Las pasiones que despierta Naná son el producto de una falacia generada por el menoscabo de la sociedad parisina de su tiempo. El espacio de Santa es, de entrada, distinto: mundo cotidiano y plural al que ingresa una mujer genuina. (260)

Y sin duda tiene razón en esto, como también me parece que la tiene en la apreciación de las distintas estéticas que rigen la escritura de ambas novelas; sin embargo, pienso que se puede replantear desde otra perspectiva el problema de la configuración espacial en Santa; es decir, que a pesar de que la novela se abra con la descripción de un espacio creado en nítidas coordenadas realistas, también puede rastrearse el modo en el que se va erigiendo el burdel y la vida prostibularia como un ámbito deliberadamente teatralizado. Habrá que ver cómo se hace y para qué en la lógica de la novela.

La creación de los espacios en la narrativa cumple una función muy importante en la medida en que en ellos se arraigan los personajes; sobre ellos se proyecta el horizonte de valores ideológicos y estéticos en el que se forja la novela y posibilitan el fluir de un tiempo que puede ser histórico o que puede ser mítico, pero que en cualquier caso, siempre determina el perfil y el destino de los personajes que los pueblan. Para el caso concreto que nos ocupa, si el burdel es caracterizado con los rasgos del teatro, los personajes que ahí se mueven adquirirán perfiles dramáticos y sus acciones serán, en gran medida, performance, en ese sentido de teatralización de su hacer.

Federico Gamboa no está haciendo en Santa un retrato de la vida prostibularia del México porfiriano, ni está dejando consignados sus recuerdos de trasnochador impenitente -ya arrepentido en el momento de la escritura-, ni un discurso apologético o simplemente condenatorio de la prostitución ni de la mujer caída: está creando un completo y complejo mundo ficcional que evoca o hace referencia a esa ciudad de México históricamente reconocible; deja que se oigan los ecos de las voces y las visiones religiosas, médicas, legales sobre la prostitución y para esto usa el filtro de las artes:

Revista Iberoamericana, Vol. LXXXI, Núm. 250, Enero-Marzo 2015, 277-292 ISSN 0034-9631 (Impreso)

ISSN 2154-4794 (Electrónico) 
la plástica, sin duda, como se ha hecho notar una y otra vez, porque es una presencia privilegiada en la novela; la escritura y también las artes teatrales.

El hecho de que se abra la novela con el patético ruego de Santa al escultor Jesús F. Contreras, para que la eternice en el mármol de su arte, a cambio de la historia que va a entregarle, es una declaración de principios y una pauta de lectura del texto que lo ubica, acaso, en la continuidad tardía de un arte modernista, estetizante, y no tanto en el naturalismo o el realismo. Estamos ante un artificio que delata una voluntad de orientar la actividad relatora hacia la consecución de una obra artística que plasme una vida, que congele un momento en un gesto sublime. No es suficiente el anecdotario que se ha desplegado para explicar esta dedicatoria al escultor; no es suficiente para entenderla en el mundo novelesco y el sentido que le imprime al todo: la historia no se cuenta para ilustrar el rigor con que puede pagarse una vida disipada o inconveniente; se articula para alcanzar una obra de arte. Y esto lo supo ver con mucho tino José Luis Martínez Suárez en su estudio: "El cuerpo en Santa deviene arte-verbal, escultórico, escénico, pictórico-, y ese destino lo rescata, en cierto sentido, de la condena moral y de la reducción experimental" (134). La historia se ofrece a cambio de una realización artística porque sólo el arte puede ser comprensivo: "Cuentan que los artistas son compasivos y buenos..." (Gamboa 66).

Esta voluntad explícita de asignar a la historia relatada el papel de una simple mediación, o pago, para alcanzar a cambio una obra de arte debiera ser más tenida en cuenta, antes de centrar tanto la disputa en el problema de la adscripción del texto a alguna de las escuelas en boga. La historia contada es así, pues, una moneda de cambio, busca conmover y suscitar "una limosna de cariño"; tal vez, en el fondo, el fin de toda producción artística sea la de promover algo parecido, aunque se formule en otros términos menos patéticos. El pacto propuesto por Santa al escultor legitima la pretensión de hacer una lectura de la obra en el seno de las artes.

\section{ESPACIO Y CONCIENCIA NARRATIVA}

Federico Gamboa eligió cuidadosamente los espacios en los que iba a desplegar los sucesivos movimientos de ascensos y descensos de la protagonista de su novela. La obra se abre con la caída de Santa al burdel y en el capítulo segundo sabemos que viene en su descenso de un mundo idílico que se despeñó como las piedras lanzadas al abismo. En el horizonte ético desde donde está articulada la perspectiva del relato, toda la historia puede verse como un continuo descenso sin freno a esos abismos prefigurados en las piedras que Santa lanzaba en el Pedregal, analogía que ella misma establece más tarde (180). Pero no puede negarse que en la propia lógica narrativa la historia también cuenta la transformación de una muchacha que, de "encogida y cerril" alcanza a encumbrarse como "cortesana a la moda". Muerte y resurrección resultan, así, términos ambiguos y

Revista Iberoamericana, Vol. LXXXI, Núm. 250, Enero-Marzo 2015, 277-292 ISSN 0034-9631 (Impreso)

ISSN 2154-4794 (Electrónico) 
de algún modo intercambiables: muere la muchacha zafia en Chimalistac para resucitar convertida en imponente prostituta triunfadora y reina de la ciudad corrompida; muere la prostituta degradada, en medio de tortuosos dolores purificantes, para hacerla resucitar en el rezo de Hipólito en el que Santa se funde con la Virgen María; su historia llega al final pero ella pide la resurrección de su cuerpo en el arte del escultor.

Este diseño de la trama marcado por la ambigüedad también tocará en lo profundo el propio tono narrativo que siempre es oscilante entre la conmiseración y el asco, la admiración vouyerista y el repudio moral. Pero estos vaivenes no pueden explicarse aisladamente como si atañeran a territorios extraños unos a otros, resultado natural de una ambivalencia ética del autor. Me parece que la ambigüedad sólo adquiere sentido si se le ve en el todo de la poética que preside la creación artística del relato. ${ }^{3} \mathrm{Y}$ algunas de estas claves pueden encontrarse en la configuración de los espacios que habitarán sus personajes, espacios que se llenarán de ecos de los diversos y contradictorios discursos sociales que alcanzan a plasmarse en la novela.

Gamboa no parece ser un novelista afecto a recrear espacios fijos, ajenos a la vida humana; en general siempre opta por trazar un espacio donde se dé el movimiento de la vida y el fluir del tiempo; no construye paisajes carentes de vida ni introduce descripciones de entornos por el mero placer de dibujante. La construcción del burdel se va haciendo conforme sus personajes se apoderan de ese espacio, lo pueblan con sus risas, con la música y con charlas intercaladas. El espacio se va configurando de acuerdo con el tipo de ruidos que ahí resuenan; así, el burdel no es aprehendido panorámicamente por el ojo observador de la voz relatora, sino que se va internando en él conforme su protagonista vaya apropiándoselo por la vía de los ojos y el oído: "[...] se escucharon risas, tuteos, el estallido de un beso y los taponazos de las botellas que el criado descorchaba" (91). Estamos ante un escenario poblado por el actuar humano y cuyo sentido moral se va figurando en el tipo de vida que ahí vibra. En esta medida los espacios pueden convertirse en entornos significativos de un modo de vida, de una moral determinada, de una crisis interna. En el espacio se proyecta la vida y ahí se despliega la conciencia contradictoria del hablante principal.

En uno de los momentos clave para entender la configuración del burdel como un entorno ético, vital, significativamente el narrador le cede la palabra a Hipólito:

Sólo que el burdel es como el aguardiente y como la cárcel y como el hospital; el trabajo está en probarlos, que después de probado, ni quién nos borre la afición que le cobramos, la atracción que en sus devotos ejercen... Usted regresará a esta casa, Santita, o a otra peor... (135)

\footnotetext{
${ }^{3}$ Tal vez resulte adecuada para el caso de Santa esta frase que utiliza Wendy Steiner explicando algunos de los enveses de la estética de principios del siglo xx: "Telling the story of a world turned transgressive is sometimes hard to distinguish from celebrating transgression" (83).
}

Revista Iberoamericana, Vol. LXXXI, Núm. 250, Enero-Marzo 2015, 277-292 ISSN 0034-9631 (Impreso) 
Obsérvese cómo la selección lexical para trazar el nexo entre vida y burdel ya es de suyo ambigua; si bien lo asocia con instituciones cargadas de valores negativos, cárcel y hospital, luego cambia su tono al hablar de la atracción que ejerce en sus "devotos" y nada más con esta elección, se instaura la ambivalencia que llega hasta el extremo implícito de equiparar burdel con santuario, templo sagrado. ${ }^{4} Y$ dije que era significativo que este parlamento se pusiera en boca de Hipólito y no del narrador porque así éste se deslinda de los implícitos valorativos que la frase encierra y descarga la responsabilidad en la perspectiva de un ciego al que, además, se le calificará de pervertido unas cuantas líneas después.

La elección de contar la historia de una prostituta conlleva la espacialidad en donde transcurrirán los sucesos: el burdel o la calle con sus tugurios. Gamboa elige ubicar la mayor parte de su relato en un prostíbulo para las clases altas y sólo hacia el final se desplaza el lente narrativo a la descripción de burdeles deprimentes. En la primera parte, el cuerpo de Santa está intacto, saludable, joven, apetecible y la misma correspondencia existe en la última parte, es tan derruido el cuerpo y la salud de Santa como su propia moral y en el espacio que habita se proyecta su degradación.

El burdel resulta el punto de partida para hacer la exploración de muy diversos ámbitos citadinos, pero siempre enfocados desde el universo de la prostitución. Ahora, si los lectores alcanzamos a atisbar de fuera hacia dentro, porque el narrador ha decidido introducirnos en la interioridad de ese ámbito, también el lente cambia y de pronto es desde las entrañas del burdel que se echa un vistazo al mundo exterior. El lector viaja en la novela por la nocturna ciudad de México, se introduce en salones de baile y llega hasta los garitos, pasando por la casa de huéspedes, hoteles, fondas, reservados de restaurantes, el hospital y los juzgados, con lo cual quedan muy nítidamente establecidas las coordenadas de ubicación del burdel y la vida burdelesca: territorio fronterizo entre los bailes y la festividad, por un lado, y, por el otro, entre el crimen y la enfermedad. Pero vale la pena hacer notar que estos recorridos son hechos a partir de la presencia de Santa en el mundo exterior, nunca sin ella.

De la atención que el narrador dedica a la recreación de los espacios, sobresale la que le merece el Tívoli Central, en una minuciosa descripción nunca elaborada para el burdel donde trabajó Santa. El narrador es muy hábil para ir cifrando en la descripción detenida los ritmos de la vida que ahí discurren, pero solamente evocados, de tal modo que la pausa descriptiva adquiere sentido ético sin desatarse de la dimensión poética;

4 Rodrigo Cánovas explora la dimensión del prostíbulo como alegoría del bien y del mal en la narrativa hispanoamericana. En particular, en el caso de Santa Cánovas observa cómo hay una serie de pistas en la novela que permiten leerla como alegoría de un templo: "[...] un templo 'a la moderna', en el cual Santa aparece como el ídolo o trofeo inmolado en el rito pagano del derroche, animado por los réprobos que se han alejado de la ciencia. Templo ‘a la moderna' como la Giralda, 'Carnicería a la moderna' de los alrededores $[\ldots]$ '. (20).

Revista Iberoamericana, Vol. LXXXI, Núm. 250, Enero-Marzo 2015, 277-292 ISSN 0034-9631 (Impreso)

ISSN 2154-4794 (Electrónico) 
así, en el bostezante jardín diurno del local: “[...] zozobran botellas vacías, colillas de cigarros y puros, en ocasiones, un mechón de cabello, un retrato despedazado, una peineta que allí arrojaron anónimas manos de alguien que padecía de celos y demandaba olvido con ese rapto de despecho iracundo y estéril" (152). Así, puede observarse cómo ni en estos momentos donde se detiene el fluir de la historia, se llega a la fijeza de un cuadro inmóvil. Gamboa parece necesitar siempre de aplicar movimiento y de enfocar desde la actitud valorativa para construir los espacios donde se despliega la vida: "Y la inmensa ciudad lasciva se regocija e ilumina porque una noche más es dueña suya" (153). Y en esta percepción del fluir de la vida en el espacio, el narrador hace abarcadora su vista, no cuenta un caso aislado e insignificante, sino que adquiere la contundencia de la vastedad.

Por este modo de construir la historia, Gamboa logra configurar la prostitución como un mundo fronterizo, movible, con distintas facetas, lugar de cruce, de encuentro, horizonte de enunciación y de conocimiento de los cauces ocultos del transcurrir de la vida. Varios críticos han acertado al señalar que el burdel funciona como un punto de conjunción de todos los otros, ${ }^{5}$ y esto es a tal grado así que la dimensión del burdel en tanto puerto de llegada de las hordas de hombres lujuriosos, se proyecta hacia el cuerpo de la prostituta, como un lugar en el que confluyen los ríos de la historia y ahí se plasma el transcurrir del tiempo: en el cuerpo de la mujer hecho territorio se va trazando el flujo de la historia, el destino de una raza:

[...] florescencia magnífica de la metrópoli secular y bella, con lagos para sus arrullos y volcanes para sus iras, pero pecadora, pecadora, cien veces pecadora; manchada por los pecados de amor de razas idas y civilizaciones muertas que nos legaron el recuerdo preciso de sus incógnitos refinamientos de primitivos; manchada por los pecados de amor de conquistadores brutales, que indistintamente amaban y mataban; manchada por los pecados de amor de varias invasiones de guerreros rubios y remotos, forzadores de algunas de sus trincheras y elegidos de algunas de sus damas; manchada por los pecados complicados y enfermizos del amor moderno. (166)

Más allá del efluvio retórico que se adueña del narrador en este fragmento, importa señalar su aguda sensibilidad narrativa para dejar inscrita en el cuerpo de la prostituta la marcha de la historia, de tal modo que el relato adquiere una dimensión abarcadora,

\footnotetext{
"The brothel, then, is not just another space among the various institutionalized spaces of instruction and production; it is also a compendium of the others. Meat shop and school, factory and cemetery, the brothel is a microcosm of society and an index of all that is wrong with the other sites" (Castillo 60). En otros términos, pero con un sentido parecido, formula la idea Rodrigo Cánovas pensando en la narrativa hispanoamericana: "El burdel aparece aquí como un modelo reducido, y desde el cual se reconstruyen por analogía los demás espacios de la sociedad como estériles y regresivos" (14).
}

Revista Iberoamericana, Vol. LXXXI, Núm. 250, Enero-Marzo 2015, 277-292 ISSN 0034-9631 (Impreso) ISSN 2154-4794 (Electrónico) 
pues a partir de la insistente recreación de ese cuerpo se puede atisbar el perfil de un pueblo, con su historia.

Entonces, en la reconstrucción de espacios concretos e incluso reconocibles en el mapa de la ciudad de México del porfiriato, Federico Gamboa no estaba funcionando como un paisajista afiliado a la estética realista o naturalista sin más, sino que en esa recreación estaba sembrando la posibilidad de construir sentidos artísticos que rebasaran lo meramente referencial y anecdótico. La atribución de valores simbólicos y casi míticos a espacios y cuerpos configurados, abre la novela hacia las diversas voces del arte. Aquí veremos en particular, la dimensión teatral en la que se va hilvanando el argumento narrativo.

\section{PRostituCiÓN Y ESPECTACULARIDAD}

Si bien muchas de las prácticas sociales están perfectamente codificadas al modo en el que se dan las actuaciones teatrales -la política, el deporte, el rito religioso-, es más o menos fácil demostrar que la práctica de la prostitución involucra una mayor dosis de espectacularidad dramática que todas las otras. La prostitución puede pensarse en términos muy amplios como teatralidad en la medida en que, en todas sus formas, ha implicado poner en exhibición un cuerpo, ${ }^{6}$ un actuar, para atrapar la mirada, la atención del receptor a quien se dirige el mensaje. Teatralidad puede entenderse como "un sistema de códigos en el cual se privilegia la construcción y percepción visual del mundo, en el que los signos enfatizan la comunicación por medio de imágenes. El mundo es percibido como escenario en el cual se actúa y los emisores de signos emiten tanto signos gestuales como visuales y lingüísticos" (50). La prostitución, en tanto práctica social, ha recibido una fuerte codificación de naturaleza espectacular en la medida en que se apoya principalmente en lo visual y en la actuación de quien ejerce el oficio, cuya gestualidad, vestuario y maquillaje debe remitir forzosamente a lo que se quiere comunicar: me ofrezco públicamente. El escenario puede ser cualquier calle de cualquier ciudad del mundo o el burdel, espacio privilegiado para la puesta en escena del espectáculo prostibulario.

Una prostituta adquiere su identidad en la negación de su pasado y en la construcción de un perfil que es, ante todo, una imagen socialmente reconocible. Prostituirse quiere decir, en gran parte, encarnar una serie de negaciones -la familia, un nombre propio, una cotidianidad - para afirmar la fantasía de los otros a partir del ofrecimiento de un cuerpo desligado de las ataduras de la faena diaria, volatilizado por la magia del fausto, del atavío y el gesto seductores desplegados en un espacio también teatralizado. La

${ }^{6}$ Se puede apreciar nítidamente cómo este sentido está en el mismo vocablo; véase el Diccionario de Autoridades que definía lo prostituido como "lo así expuesto al público, y entregado a todos".

Revista Iberoamericana, Vol. LXXXI, Núm. 250, Enero-Marzo 2015, 277-292 ISSN 0034-9631 (Impreso)

ISSN 2154-4794 (Electrónico) 
prostituta siempre representa un papel; es corporeidad ante todo y el cuerpo es el punto de partida para la espectacularidad. ${ }^{7}$

Es todo este proceso el que Gamboa reconstruye en su novela para ofrecer al lectorespectador, la imagen de un personaje que se prostituye conforme aprende a dominar las técnicas de la representación que exige el papel de la cortesana: Santa niega su identidad pasada, esconde avergonzada y culpable partes de su atuendo de campesina devota-el escapulario-, finge mantener un nombre que, fatal y lúdicamente, desfigura su significado primigenio y pasa a connotar un sentido inverso: recibe un segundo bautismo que invierte el sentido propuesto en el primero; es ataviada con una indumentaria adecuada que habrá de caracterizarla como prostituta elegante y a la moda; aprende la gestualidad que debe encarnar y la apropiación apresurada de este nuevo papel le traza un destino ineludible: la imposibilidad de dejar de ser puta. Al labrarse una imagen tan marcada socialmente, se establece una radical frontera con la imagen de la mujer pura y casta y no hay camino de regreso posible, porque se trata de la construcción de una presencia que es ante todo expresión de una moral.

La teatralidad que implica el oficio está constantemente marcada a lo largo de la novela y los guiños son de diversa naturaleza; pero uno de los paralelismos más fructíferos es el establecido con los toreros, como puede apreciarse desde las primeras páginas:

Todas se despeñaron por la empinada escalera, en tropel de gritos y empellones -una verdadera y desaforada carga contra el dinero-, todas se alisaban el cabello, se mordían los labios hasta ponerlos de un rojo subido, pegaban los codos a la cintura para que los senos resaltaran; todas, en su andar, marcaban el paso con las caderas, a semejanza de los toreros cuando desfilan formados en la plaza, y todas arrastraron adrede, por las gradas, los tacones de las zapatillas (Gamboa, Santa 86).

Esta primera alusión resulta una especie de prefiguración del mundo de los toreros que atravesará parte de la trama de la novela y funcionará como una especie de motivo oculto para analizar y recrear artísticamente la prostitución como performance.

La relación entre el Jarameño y Santa se presenta siempre como una especie de combate; hay una soterrada competencia erótica entre ambos personajes que se atraen y se repelen hasta llegar al amancebamiento, mismo que culminará fatal e inevitablemente en la infidelidad de Santa y en una de las expulsiones violentas que irá sufriendo el personaje. Este desenlace que es explicado por el narrador como el resultado del hastío de Santa y como una manifestación de su absoluta corrupción espiritual, esconde otra

7 Véase sobre el tema de las relaciones del cuerpo con la teatralidad el artículo de Alfonso de Toro: "Introducción: teatro como discursividad espectacular-teórico-cultural-epistemológica-mediáticacorporal" (9-72).

Revista Iberoamericana, Vol. LXXXI, Núm. 250, Enero-Marzo 2015, 277-292 ISSN 0034-9631 (Impreso)

ISSN 2154-4794 (Electrónico) 
motivación, ahí aludida, pero nunca hecha explícita del todo: se trata de la competencia que se ahonda entre ellos por la espectacularidad del torero y la reclusión de Santa.

No hay espacio para pensar que Santa esté aburrida de su relación erótica con el Jarameño, puesto que el propio narrador se ha encargado de marcar una y otra vez la pasión con la que se prodigaban caricias y se entregaban al amor corporal. Santa está celosa de la figura del torero, de cómo se atavía meticulosamente para ser mirado por los espectadores, de cómo desfila teatral en la plaza, mientras que ella no tiene acceso a esa exhibición pública, a la que ya se había acostumbrado. Es digno de ser notado cómo el ritual de vestir al torero merece varios párrafos, como en su momento se le dedica al ritual seguido por Santa para ataviarse como prostituta. El narrador deja muy claramente establecido el aire artístico que asume el Jarameño, la egolatría con que se valora ante el espejo y los celos que empieza a despertar en Santa:

Santa experimentó inopinados e instantáneos celos, comprendió por qué estos hombres arrancan aplausos a su desfile, por qué engendran pasiones hasta en algunas damas encumbradas. Sus defectos, sus vicios se descubrirán después, mucho después, en la plaza son el color y la curva, el arte y la fuerza, la agilidad y la maestría [...] (241).

Aquí ya está sembrada la disputa soterrada entre ambos y el fondo de la decepción de Santa es porque está insatisfecha y descontenta con el papel de reclusión que se le ha asignado, de mujer que debe permanecer puertas adentro, esperando y rezando por su hombre. Ella es una actriz añorando la exhibición pública, el reconocimiento que, en cambio, se reserva para sí el torero:

Ella teníase imaginado cosas distintas, lo que él prometía en sus visitas donde Elvira; una continua juerga, la guitarra y la navaja, la manzanilla y la plaza de toros, Santa en lugar visible, el Jarameño brindándole los bichos que estoqueara, el público interiorizándose de sus amores, aplaudiendo a Carmen más que a Escamillo [...] (245).

Esta nostalgia por el aplauso popular es lo que delata la profundidad de la corrupción moral de Santa que ya no tendrá remedio, según apunta el narrador - "porque su perdición ya no tendría cura porque se habría maleado hasta sus raíces [...]”-. Parece así, hacerse radicar la salud o la descomposición espiritual de las mujeres en su predisposición casi natural y perversa a la exhibición pública o a su conformidad para mantenerse recluidas entre cuatro paredes.

Cuando Santa rompe el vínculo que la unía con el Jarameño se reintegra al burdel, vuelve a asumir su papel de mujer fatal y es muy significativo un párrafo que sirve de transición de un estado a otro, párrafo a cargo del narrador, en apariencia inocuo, pero que funciona claramente como un indicio casi simbólico de la vuelta de Santa a su vida anterior:

Revista Iberoamericana, Vol. LXXXI, Núm. 250, Enero-Marzo 2015, 277-292 ISSN 0034-9631 (Impreso)

ISSN 2154-4794 (Electrónico) 
Y distraídamente, púsose la chica a considerar despacio los cristales de las peluquerías que albergaban máscaras y caretas, pelucas y barbas, postizos y disfraces por ser primer domingo de carnaval (250).

Las máscaras, los disfraces son los instrumentos de los que Santa se vale para actuar en la vida como prostituta, ellos la expresan y en este instante parece instaurarse la contemplación abismada de su vida. ${ }^{8}$ Por eso la suspensión momentánea del transcurrir de la anécdota. Y tampoco es inocente que la vuelta de Santa al burdel ocurra justamente en temporada de carnaval y que la reinstalación del personaje en la vida prostibularia se selle con su asistencia al baile de disfraces, vestida para la ocasión: se nombra, de esta manera, simbólicamente la definitiva pertenencia de la protagonista a la vida ilusoria, teatralizada de la prostitución.

Líneas arriba dejé apuntada la idea acerca de la importancia de la corporalidad en la teatralización. En el cuerpo que se atavía de determinada manera, que actúa una gestualidad y que se posiciona inconfundiblemente en el espacio, se cifra el oficio de la prostitución y para que pueda ser eficaz debe atraer la mirada del espectador. En otras palabras, el espectáculo que se ofrece debe ser lo suficientemente llamativo y atrayente para cerrar la posibilidad de la duda o incluso la ambigüedad; debe ser provocativo y lo es en todos los sentidos de la palabra. Sensible a este hecho, Claire Solomon apunta como una primera hipótesis de trabajo para explicar el proceso de configuración de la prostituta literaria la duplicidad que encarna:

$[\mathrm{H}]$ abita un mundo fronterizo poblado por simuladores, en el cual la verdad se convierte, inexorablemente, en mentira, y -en ocasiones- la mentira en verdad. Se destaca también, correlativa a esta duplicidad, una sobrerrepresentación del cuerpo de la prostituta, al cual se le atribuye un poder oculto y amenazante porque su capacidad seductora es autónoma de su propio deseo sexual. Este régimen de visibilidad convierte a la prostituta de facto en simuladora hasta el punto que pureza, honestidad y pudor se convierten en un gesto más de una sexualidad teatral y embustera, ya que el pudor viene acompañado de hiperbólicas descripciones del cuerpo que habla por la prostituta mientras subvierte su palabra (159).

El cuerpo de la prostituta se levanta como una amenaza por la inconfundible evocación a la sexualidad que encarna. Los polos entre decencia y deshonra quedan claramente establecidos en las coordenadas de la visibilidad y la invisibilidad del cuerpo

8 No quiero dejar pasar la ocasión de sugerir la relación de la máscara con el maquillaje del que se vale la prostituta en una ambigüedad latente, heredada del uso que las culturas antiguas le daban a la máscara: "[las putas] se maquillan no para afirmar su propio rostro, sino para expresarse como un otro [...] si el maquillaje esconde tras de sí un rostro distinto es porque hay también una necesidad de protección" (Gaona 133).

Revista Iberoamericana, Vol. LXXXI, Núm. 250, Enero-Marzo 2015, 277-292 ISSN 0034-9631 (Impreso) ISSN 2154-4794 (Electrónico) 
femenino. Un cuerpo impuro está ahí, expuesto a la mirada pública. Por eso la insistente recurrencia a lo largo de la novela a la corporalidad de Santa.

Ahora bien, es evidente la aparente contradicción entre una constate referencia a la carnalidad de Santa, las demoradas descripciones de partes de su cuerpo y la ausencia de recreaciones sobre su sexualidad ya como prostituta. Así lo apunta Debra A. Castillo: "Representations of the prostitute specifically elide her sexuality, making it abstractly present by displacement onto her body, but all the more hyperdetermined and false" (39). Y no deja de ser sorprendente este silencio dada la audacia de Gamboa para pintar, en otros momentos, un completo cuadro del placer experimentado por la protagonista: su iniciación sexual con el alférez Marcelino y más tarde, las incursiones del narrador en la privacidad de la entrega al Jarameño y el relato del último placer experimentado por la prostituta ya decadente en brazos del adolescente, antes de sucumbir definitivamente al alcoholismo y a la degradación total. Sin embargo, hay un silencio absoluto alrededor del ejercicio sexual de Santa cuando cobra por sus servicios. ¿Por qué sí resultó posible introducir el erotismo en una novela escrita en el porfiriato, incluso con bastante audacia, pero se silenciaba todo lo relativo a la sexualidad prostituida, si esa vida es la que está intentando recrearse?

Hay varias respuestas hipotéticas a esta pregunta, pero enunciaré sólo dos, para llegar luego a las consecuencias literarias de este hecho: 1) hablar abiertamente de la vida sexual de la prostituta implica, sin duda, hablar de las sexualidad reprimida, problemática o simplemente escandalosa de quienes asisten al burdel; en otras palabras, es hablar de la sociedad porfiriana del momento desde las entrañas mismas de la privacidad y eso no sería admisible desde ningún punto de vista. ${ }^{9}$ 2) Se tendría que recrear el asco, la repulsión que le provoca el hecho a la prostituta, pero también habría que captar los raptos de placer que esas mujeres pueden experimentar y esto implicaría echar abajo el gran mito sobre el que se funda la construcción de la imagen de la prostituta como una víctima, digna de compasión. ${ }^{10}$

Para eludir entonces estos inconvenientes, Federico Gamboa opta por enfocar su lente en el cuerpo de Santa, pero un cuerpo que es visto parcial y fragmentariamente, a través del filtro de la mirada inocente de Genaro, por ejemplo, o por el camino de la metáfora (su cuerpo como fruta apetecible, carne sabrosa) o en la irrealidad del gesto

9 En otro trabajo he expuesto la hipótesis de que es ésta una de las razones para que las novelas hispanoamericanas que recrean la vida de las prostitutas hayan sido tan reacias a darles la palabra directa para que ellas narren desde su propio horizonte: "El silencio de la prostituta revela la estrecha relación de la novela con la ideología de su tiempo porque se le niega la voz no solamente porque sea mujer, que ya es razón suficiente para hacerla callar, sino porque sus ojos han visto demasiado y su palabra sería el yo acuso más fuerte que pudiera pronunciarse contra todo el hipócrita sistema burgués" (516).

10 La propia Santa calla esta eventualidad en la dedicatoria al escultor y en la rotunda afirmación de que su cuerpo ha sido "magullado y marchito por la concupiscencia bestial de toda una metrópoli viciosa" (66), y así, cierra la puerta a cualquier atisbo de placer que pudo haber sentido.

Revista Iberoamericana, Vol. LXXXI, Núm. 250, Enero-Marzo 2015, 277-292 ISSN 0034-9631 (Impreso)

ISSN 2154-4794 (Electrónico) 
teatral. En esta elección narrativa se aprecia, por un lado, el apego de Gamboa a los principios ideológicos de su tiempo y de su sociedad y, por otro, la voluntad de inscribir su texto en los marcos de la ficcionalización estetizante.

\section{LA MIRADA EN SANTA}

Si toda puesta en escena supone la presencia de un observador que atestigüe y confirme que el mensaje que se le ha dirigido ha logrado captar su atención, en el caso de la prostitución la interpelación es particularmente importante: de no haber la recepción adecuada no opera la magia buscada y entonces el performance deriva en un espectáculo extraño y condenable. Ahora, es preciso hacer notar que hay un amplio abanico de posibles respuestas sociales, fuertemente codificadas, dependiendo de quién reciba el estímulo visual: cómo deben responder las mujeres castas, cómo los médicos y vigilantes del cumplimiento de la ley, cómo los clientes que asisten al burdel, adentro y afuera. Es innegable, sin embargo, que la visibilidad de la prostituta ha generado, en todos los tiempos, una molestia que se expresa de muy diversas maneras; y una de las más evidentes es el pudor ofendido que muestran las mujeres decentes ante el temor de ser confundidas con ellas, de ahí la constante reglamentación tendiente a impedir la posibilidad de esta confusión. ${ }^{11}$

Federico Gamboa resultó un agudo observador de la inmensa variedad de respuestas que provoca la existencia de la prostituta y del burdel, registró con minucia y precisión las escalas tonales que se dan en el proceso siempre contradictorio de la mirada social hacia el cuerpo de la prostituta. No obstante lo anterior, hay que hacer notar la casi total ausencia en su novela de mujeres castas, ninguna adquiere perfil de personaje, pues como anota Álvaro Uribe: “Todas las mujeres que desfilan por el relato, con excepción de la madre de Santa, son putas y más o menos susceptibles de maldad. Como no sea para expulsar a la protagonista de una iglesia donde la juzgan indigna de refugiarse, las damas decentes y creyentes del Porfiriato están piadosamente excluidas de la narración" (250). Y esta ausencia hace más decisivas las fronteras entre el mundo pecaminoso y el respetable. Es indicador de la imposibilidad, en el horizonte estético de Gamboa, de que se intersequen en algún punto, aunque en el hondo sentido moral hay un débil puente que no deja de apuntar el narrador sobre estas damas principales: "[...] tampoco era fácil que supiese [Santa] que alguna de ellas guardaba en su conciencia faltas tan leves como un adulterio consentido por la aristocracia a que pertenecía" (177), y con

${ }_{11}$ Ana María Atondo Rodríguez consigna cómo las Ordenanzas en la Nueva España procuraban impedir que las mujeres públicas se presentaran en las iglesias y en sitios concurridos vestidas igual que las damas decentes y además se reglamentó contra la ostentación en los vestidos y los accesorios porque esto le parecía afrentoso a las señoras pudientes de la sociedad novohispana (143-144).

Revista Iberoamericana, Vol. LXXXI, Núm. 250, Enero-Marzo 2015, 277-292 ISSN 0034-9631 (Impreso) ISSN 2154-4794 (Electrónico) 
este comentario se anulan los abismos morales entre mujeres honestas y prostituta, pero no los sociales.

Alcanzan a plasmarse en la novela rastros de esta respuesta social hacia la presencia de Santa, no sólo en esta ya mencionada explícita agresión de las mujeres en el templo de donde es arrojada la protagonista. Santa, en el momento de la transición entre su ser campesina y llegar a convertirse en prostituta, intuitivamente intenta hurtar el cuerpo a las miradas masculinas y, sin embargo, las siente sobre sí, acusadoras y esta sensación constituye el preludio del cambio radical que va a sufrir su vida, su identidad, al irse introduciendo en el burdel por primera vez: "Y sin aguardar más, echóse a andar de prisa, inclinando el rostro, medio oculto el cuerpo todo, bajo el pañolón que algo se le resbalaba de los hombros; cual si la apenara encontrarse allí a tales horas, con tanta luz y tanta gente que de seguro la observaba, que de fijo sabía lo que ella iba a hacer" (70). Será la mirada de los otros la que vaya otorgándole el nuevo perfil a su vida y a partir de la mirada se formula la valoración moral que ella habrá de introyectar. Tampoco es gratuita la negación posterior en boca del narrador: "La verdad es que nadie, fuera de los ociosos parroquianos del fonducho, paró mientes en ella [...]". Y es que en estos momentos, ella todavía no tiene una existencia visible, su cuerpo todavía no está en el escenario prostibulario.

Santa se desplaza por la ciudad, pero es preciso anotar que sólo lo hace en coche; sólo mira el mundo a través de la ventanilla protectora del coche en el que se traslada para asistir con otras prostitutas y sus clientes, por ejemplo, a la ceremonia del grito y hasta su resguardo apenas le llega un vago eco de las voces populares que los increpan: "Abajo los rotos" (143). Santa no siente ni puede pertenecer al mundo, a la patria, por eso resulta un espectáculo asombroso y conmovedor asistir a la congregación de tanta gente que celebra un acontecimiento histórico que para ella resulta teatral y ajeno.

Santa, al parecer, sólo tiene vida nocturna. No ocupa ningún espacio de vida cotidiana que no sea el de los teatros, el del Tívoli, en los gabinetes reservados del club de señoritos y, por supuesto, el burdel donde trabaja. Santa no está expuesta a las miradas ajenas a su mundo. Sus contactos con otros habitantes de la ciudad son esporádicos, se trata de muchedumbres indistinguibles, si acaso un taxista que la conduce. Interesa hacer notar que en la convivencia de Santa en la pensión a donde la lleva el Jarameño se borran los signos de su oficio, allí representa otro papel ya ajeno, del que, sin embargo, guarda algunos recuerdos provenientes de su mocedad en el campo. Santa, al hacerse prostituta, pierde los nexos verdaderos con la vida pública, a pesar de la paradoja de tratarse de una mujer "pública".

Vale la pena anotar un aspecto más de este destino teatral de la prostituta que también trabaja Gamboa en su novela: la mujer es pública en la medida en que representa el guión, repetido hasta la saciedad, de lo más íntimo, lo más privado, lo menos público de la vida, de tal forma que la vivencia de la intimidad constituye la culminación de la

Revista Iberoamericana, Vol. LXXXI, Núm. 250, Enero-Marzo 2015, 277-292 ISSN 0034-9631 (Impreso)

ISSN 2154-4794 (Electrónico) 
representación teatral. Bajo este supuesto Gamboa recrea el asco y el desprecio que le inspiran los hombres a Santa, y sin embargo, es una cortesana triunfadora porque puede provocar en los hombres, sus clientes, el efecto ilusorio del amor; ellos juegan a la fantasía de ser queridos por Santa y el pacto ficcional ahí se cierra: "-iÁmame! -imploraban entre billetes de banco y rabiosas caricias-, ¡ámame un instante a lo menos!" (127). Pero el cliente-espectador de la puesta en escena de la prostituta no advierte que detrás del espectáculo hay un ser que participa en sentido inverso de lo que está representando, al vivir esa "mezcla de desdén y de ira hacia todos..."Y así, la representación que también encarnará el cliente, está destinada al fracaso, a la incomunicabilidad porque se trata de dos órdenes distintos de teatralidad, con dos intencionalidades y recursos diferentes.

Toda la hostilidad, la amenaza de la condena social la vive Santa en la imagen que le devuelve la mirada de los hombres con los que, por su oficio, debe tratar: médicos, encargados de la revisión ginecológica, clientes-en particular Rubio y elJarameño-, las otras prostitutas, Hipólito -y no es indiferente que sea, precisamente ciego-y el pequeño pícaro lazarillo del pianista. El narrador no tiene ninguna dificultad para desplazar su punto de mira al de estos personajes que observan a Santa de muy diversos modos. Cada mirada le sirve al narrador para completar el complejo cuadro de percepciones físicas, morales, siempre valorativas con las que es configurada la protagonista. Con todas las posibles variaciones en las que pueda entornarse la mirada, la prostituta va imponiendo su presencia y acreditando su triunfo de cortesana fina. A veces es fruta que desea morderse, alguien la ve como carne fresca, otros ven la curva comba de su cadera de tentación, lo constante es la fragmentación del cuerpo de la mujer, que la cosifica. En la mirada de los otros se siembra siempre la identidad y el sentido moral de una existencia prostituida. La recepción ambigua entre la población masculina, que va de la atracción al disimulo hipócrita, la recrea inmejorablemente Gamboa en el juicio al que deben asistir las prostitutas. La presencia de ellas ante el juzgado no difiere nada de la aparición de los actores en la escena, indicación de que empezará la función:

¡La conmoción que originaban al presentarse en la audiencia! En las gradas, un oleaje; un estremecimiento perceptible entre los miembros del tribunal, en plena plataforma, bajo el mismísimo dosel; una general fosforescencia en los ojos de los viejos, de los jóvenes, de casados y solteros, de serios y alegres; un deseo palpitante, tangible, en los rostros vueltos a las prostitutas que iban compareciendo resueltas [...] (286-287).

La mirada que recibe la prostituta nunca es indiferente o "natural", está siempre marcada por la valoración de los otros, a veces cómplice, de deseo, con mucha frecuencia de reproche, pero en esas miradas se va forjando el destino de una existencia prostituida.

Santa nunca recibe una mirada diurna. Todas han de ser a la luz difusa de las bombillas del burdel, del teatro, tras el coche que la oculta. Siempre habrá un filtro que impida la visión directa del cuerpo de la cortesana, por ello no puede ser configurada en la novela

Revista Iberoamericana, Vol. LXXXI, Núm. 250, Enero-Marzo 2015, 277-292 
como un personaje de vida diurna, cotidiana; está destinada a ser apreciada siempre en su "traje de campaña", porque ese ámbito nocturno y su disfraz son los que le han dado su identidad. De ahí la importancia que tiene la ceguera de Hipólito: su destino está cifrado en la imposibilidad de apreciarla y valorarla con los ojos de la tentación que entornan todos los hombres. Por eso es el único que puede llegar, finalmente, al fondo de ese corazón invisible para todos. Eso lo condena y eso lo protege a la vez, como él mismo lo afirma: "¡Ya veo a Santita, ya la vi, y bendigo a Dios porque soy ciego y no he de verla como la miras tú!" (190). A él le estuvo vedado presenciar el espectáculo de Santa en el escenario del prostíbulo y por ello sólo para él Santa no es teatral, de ahí que la representación que encarnen juntos, en el momento de la unión amorosa, no carnal, sea la de un cuadro escultórico, aunque esté representado como la inmovilidad teatral del momento de cierre. Pero ha cesado el movimiento, parece el telón a punto de caer:

Y a la débil flama de la vela, que zozobraba en el nimbo de las sombras del cuarto, destacábase el grupo simbolizando el ciego con aquella paloma en su hombro y con aquella mujer a sus pies, una escultura trágica del irremediable y eterno sufrimiento humano $[\ldots](338)$.

En esta escena culminante, Santa ha dejado para siempre de ser prostituta, por ello el gesto congelado de la estatua que negará la actuación.

Al integrar en su trabajo literario las posibilidades expresivas de las otras artes, y en particular la del teatro, Gamboa, sin embargo, está dejando sembrada una tensión irresoluble en el seno de su creación novelesca y que ha sido decisiva en el destino interpretativo que ha sufrido su texto: el atavío del mundo que recrea, la disposición de espacios y tiempos para una celebración, la del cuerpo y la alegría de la carne, que termina convertida en una triste mascarada, despojada de cualquier reminiscencia festiva, jocosa, o mínimamente placentera. Gamboa, por convicción ideológica, tributario de su momento histórico al fin de cuentas, decidió renunciar a la posibilidad de plasmar la faceta alegre del espectáculo burdelesco; no pudo ver que si pintaba la fuerza de un cuerpo joven, saludable y bien vestido, había ahí un poder arraigado en la vida, de cara al porvenir, no sólo hacia la enfermedad y la muerte. La moral dominante ganaba la batalla una y otra vez a la ambigüedad artística. Por eso se silencian las risas y resalta el llanto, a cada posibilidad del brote de la alegría la trama desanda el camino y se vuelve hacia la profundización de la desgracia y entonces la lógica narrativa implica que la risa o la sensación de bienestar es siempre preludio de un golpe más atroz del destino, de triunfo de la infelicidad o aun del crimen. La espectacularidad postulada por la novela, siempre cede a las fuerzas oscuras de la tragedia y así se minimiza la insinuación del poder subversivo que anida en la vida que se está recreando.

Revista Iberoamericana, Vol. LXXXI, Núm. 250, Enero-Marzo 2015, 277-292 ISSN 0034-9631 (Impreso)

ISSN 2154-4794 (Electrónico) 


\section{FUENTES CITADAS}

Atondo Rodríguez, Ana María. El amor venal y la condición femenina en el México colonial. México: Instituto Nacional de Antropología e Historia, 1992.

Cánovas, Rodrigo. Sexualidad y cultura en la novela hispanoamericana: La alegoría del prostíbulo. Santiago: LOM ediciones, 2003.

Castillo, DebraA. Easy Women. Sex and Gender in Modern Mexican Fiction. Minneapolis: U of Minnesota P, 1998.

Diccionario de Autoridades. Ed. Facsimilar. Madrid: Gredos, 1976.

Franco Bagnouls, Lourdes. "Guiños espaciales entre Santa y Naná". Santa, Santa nuestra. Rafael Olea Franco, ed. México: El Colegio de México, 2005. 255-261.

Gamboa, Federico. Santa. 1903. Javier Ordiz, ed. Madrid: Ediciones Cátedra, 2002.

Gaona, Luis Carlos. Al filo de la calle. Hacia una analítica y una semiótica del amor mercenario: ensayo. Medellín: Concejo de Medellín, 1997.

Martínez Suárez, José Luis. El mundo de Santa. Xalapa: Gobierno del Estado de Veracruz, 2005.

Munguía Zatarain, Martha Elena. "El Cronotopo del burdel en la literatura latinoamericana". Proceedings of the Eleventh International Bakhtin Conference: XI Conferencia Internacional sobre Bakhtin: Curitiba, July 21-25, 2003. Carlos Alberto Faraco, et al., eds. Curitiba: UFPR, 2003. 511-516.

Prendes, Manuel. "Teatralidad y simbolismo: acerca de la configuración del espacio en las novelas de Gamboa". Santa, Santa nuestra. Rafael Olea Franco, ed. México: El Colegio de México, 2005. 353-363.

Salaün, Serge. "Política y moral en el teatro comercial a principios del siglo xx". Boletín de la Fundación Federico García Lorca 19-20 (1996): 27-47.

Solomon, Claire. “¿Cuánto cuesta el presente? El tiempo de la prostitución en Santa”. Santa, Santa nuestra. Rafael Olea Franco, ed. México: El Colegio de México, 2005. 159-170.

Steiner, Wendy. Venus in Exile. The Rejection of Beauty in Twentieth-Century Art. New York: Free Press, 2001.

Toro, Alfonso de. "Introducción: teatro como discursividad espectacular-teórico-culturalepistemológica-mediática-corporal". Estrategias postmodernas y postcoloniales en el teatro latinoamericano actual. Hibridez-Medialidad-Cuerpo. Alfonso de Toro, ed. Madrid: Iberoamericana, 2004. 9-72.

Uribe, Álvaro. "Historia de dos beldades". Santa, Santa Nuestra. Rafael Olea Franco, ed. México: El Colegio de México, 2005. 241-253.

Villegas, Juan. Para la interpretación del teatro como construcción visual. Irvine: Gestos, 2000.

Revista Iberoamericana, Vol. LXXXI, Núm. 250, Enero-Marzo 2015, 277-292 ISSN 0034-9631 (Impreso)

ISSN 2154-4794 (Electrónico) 